\title{
25. \\ JAŠA PRODANOVIĆ U DRUGOM \\ SVETSKOM RATU
}

\section{Aleksandar Lukić}

UDK: 32-05Prodanović, J.“194“

Prethodno priopćenje

Sažetak: Publicista, književni kritičar i politički radnik Jaša Prodanović (1867-1948) bio je jedan od najistaknutijih boraca za uspostavljanje republikanskog oblika državnog uređenja jugoslovenske države nastale 1918. godine. Bez obzira na politički neuspeh Jugoslovenske republikanske stranke, čiji je jedan od osnivača bio 1920, u političkom životu Kraljevine Jugoslavije uporno se zalagao za uspostavljanje federativne republike jugoslovenskih naroda. Od ovih načela nije odstupao ni onda kada je bilo najteže za politički rad, u vreme šestojanuarske diktature i tokom Drugog svetskog rata. U radu se prikazuje njegovo delovanje uoči i tokom Drugog svetskog rata u Jugoslaviji, sa osvrtom na njegovu ulogu krajem rata i delovanje u Narodnom frontu Jugoslavije 1944-1945.

Ključne reči: Jaša Prodanović, Jugoslovenska republikanska stranka, Drugi svetski rat, Narodni front, komunisti, republika

d Solunskog procesa 1917. Jaša Prodanović je zbog izraženog nedemokratskog ponašanja regenta Aleksandra Karađorđevića prekinuo svaku vezu sa monarhijskim oblikom vladavine i dinastijom Karađorđevića. Odranije poznat kao republikanac u političkom životu Kraljevine Srbije - nakon pokušaja uspostavljanja republikanskog oblika vladavine u Srbiji u vreme Majskog prevrata 1903 - uveren da je Solunski proces „unapred smišljena zavera da se nevinim ljudima uzmu glave" od strane princa-regenta i predsednika vlade Nikole Pašića, stupio je posle procesa u otvorenu političku borbu protiv monarhije, propovedajući uspostavu federativne republike buduće države jugoslovenskih naroda. ${ }^{2}$

U poslednjem razgovoru sa regentom pokušao je da ga ubedi u nepravilnost i nepravednost smrtne presude nad osuđenim srpskim oficirima. Na regentovo pitanje, između ostalih, o njegovom republikanizmu odgovorio je:

Rad je deo projekta Instituta za noviju istoriju Srbije Srbi u jugoslovenskom i međunarodnom kontekstu: unutrašnji razvitak i položaj u evropskoj/svetskoj zajednici (br. 47027) koji finansira Ministarstvo prosvete i nauke Republike Srbije.

2 Spomenica Jaše M. Prodanovića, Beograd 1958., 184.; Ljubinka TRGOVČEVIĆ, Naučnici Srbije i stvaranje jugoslovenske države 1914-1920, Beograd 1986., 259.-268. Više o Majskom prevratu: Dragiša VASIĆ, Devetsto treća (Majski prevrat), Beograd 1925.; Slobodan JOVANOVIĆ, Vlada Aleksandra Obrenovića, II, Beograd 1990.; Olga POPOVIĆ OBRADOVIĆ, Parlamentarizam u Srbiji od 1903. do 1914. godine, Beograd 1998.; Suzana RAJIĆ, Aleksandar Obrenović. Vladar na prelazu vekova - sukobljeni svetovi, Beograd 2011. 
Republiku neće dovesti čista teorijska propaganda republikanskih načela. To ni u jednoj zemlji ne biva tako, nego se republike javljaju kad monarhije dozlogrde narodu. (...) Narodna masa može mnogo da trpi, ali kad 'pređe dara meru', javljaju se bune, revolucije i zavere. To je lekcija svetske istorije. Ako princ ne bude vladao kako treba, on će sam pojačati (...) republikanski pokret. ${ }^{3}$

Od ovog razgovora Jaša Prodanović više nije sreo Aleksandra Karađorđevića. Posvetio se širenju republikanskih ideja među Srbima i Jugoslovenima u izbeglištvu i stvaranju jakog republikanskog pokreta. Zajedno sa Ljubomirom Stojanovićem, filologom i istoričarem, takođe republikancem, zalagao se tokom 1918. da jugoslovenska država bude osnovana kao republika. Monarhija, pobednik iz Prvog svetskog rata, pokazala se jakom i stabilnom.

Bez obzira što im akcije za uspostavljanje federativne jugoslovenske republike nisu uspele, dvojica republikanskih vođa uložili su veliki trud u organizovanje republikanske stranke u Srbiji tokom 1918-1919. Iako ih većina političkih drugova iz Samostalne radikalne stranke nije podržala u poduhvatu, uspeli su da krajem januara 1920. u Beogradu osnuju Jugoslovensku republikansku stranku (JRS). Jedna od četiri političke partije koja je u Kraljevini Srba, Hrvata i Slovenaca/Jugoslaviji imala u svom nazivu naslov ,jugoslovenski", JRS se zalagala za federativnu jugoslovensku republiku po ugledu na švajcarsko i francusko državno uređenje. ${ }^{4}$ Nije podržavala revolucionarne metode promene oblika $\mathrm{dr}$ žave i socijalnih odnosa u društvu, ali je komunistima pružala podršku svaki put kada su ih monarhijske vlasti proganjale (primer Obznane). Ljubomir Stojanović bio je predsednik sve do smrti 1930, iako je već od proleća 1929. stranačkim poslovima stvarno rukovodio Jaša Prodanović.

Šestojanuarska diktatura zabranila je, između ostalog, rad političkih partija u cilju uspešnijeg ostvarenja politike integralnog jugoslovenstva. Jaša Prodanović je sa Glavnim odborom raspustio JRS sve dok se ne budu stekli puni demokratski uslovi za slobodan politički život u Kraljevini Jugoslaviji. Ni kada je stega diktature popustila posle Oktroisanog ustava kralja Aleksandra 1931. i njegove smrti oktobra 1934, Jaša Prodanović nije hteo da se JRS aktivira u političkom životu Kraljevine i na taj način pruži legitimitet diktaturi. ${ }^{5}$ Ipak, sve komplikovanije i opasnije spoljnopolitičke okolnosti posle dolaska nacista na vlast u Nemačkoj 1933. primorale su ga vremenom na izlazak iz političke apstinencije, pogotovo što su se nemačke spoljnopolitičke ambicije približavale granicama Kraljevine Jugoslavije. ${ }^{6}$

Nacistička Nemačka je marta 1938. izvršila anšlus Austrije i izbila na severne međe jugoslovenske države. Sve je manje bilo garancija da se agresivni severni sused neće mešati u

\footnotetext{
Spomenica Jaše M. Prodanovića, 185.

Švajcarski ili francuski federativni oblik republikanskog državnog uređenja jugoslovenske države zastupali su Jaša Prodanović i većina članova Glavnog odbora JRS, dok je shvatanjima predsednika stranke Ljubomira Stojanovića bio bliži „amerikanski” predsednički republikanski sistem države. U program stranke uneta je prva koncepcija, što se nije negativno odrazilo na saradnju Ljube Stojanovića sa Jašom Prodanovićem i stranačkim drugovima. Videti: Nikola STANAREVIĆ, Jugoslovenska republikanska stranka I (osnivanje i njen rad do 1941), Arhiv Srpske akademije nauka i umetnosti, Beograd (dalje: Arhiv SANU), Zaostavština Nikole Stanarevića, 14329; o pojedinim stavovima srpskih republikanaca videti: Branislav GLIGORIJEVIĆ, „Državno i društveno uređenje Jugoslavije u gledištima srpskih republikanaca (1919-1925)", Istorija XX veka, 3/1985., br. 2, 7.-33.

Jaša M. PRODANOVIĆ, Sporazum Udružene opozicije i Seljačko-demokratske koalicije (Arhiv SANU, Zaostavština Jaše M. Prodanovića, 14706/6). O političkoj opoziciji u vreme šestojanuarske diktature: Todor STOJKOV, Opozicija u vreme šestojanuarske diktature 1929-1935, Beograd 1969.; o Udruženoj opoziciji i njenoj ulozi u političkom životu Kraljevine Jugoslavije: Mira RADOJEVIĆ, Udružena opozicija 1935-1939, Beograd 1996.

6 O dolasku nacista na vlast u Nemačkoj i njihovoj unutrašnjoj i spoljnoj politici: Andrej MITROVIĆ, Vreme netrpeljivih. Politička istorija velikih država Evrope 1919-1939, Beograd 2012.
} 
unutrašnje poslove Kraljevine Jugoslavije i pokušati da iskoristi njene unutrašnje slabosti u svoju korist, prvenstveno nerešeno hrvatsko pitanje, koje je opterećivalo funkcionisanje jugoslovenske državne celine. Politička razdrobljenost srpskih građanskih partija nije bila prevaziđena ni u suočavanju sa državnom krizom i započetim svetskim ratom 1939. ${ }^{7}$ Jaša Prodanović u ovakvim okolnostima nije mogao da ne kaže svoje i mišljenje republikanaca o unutrašnjoj politici zemlje i iznese predloge za rešavanje teških pitanja, u prvom redu hrvatskog, te da se, kada je ono prividno rešeno avgusta 1939, ne izjasni o negativnim i pozitivnim stranama srpsko-hrvatskog sporazuma. ${ }^{8}$ Svojim objavljenim i neobjavljenim napisima uoči Drugog svetskog rata u Jugoslaviji kritikovao je nedemokratsko delovanje vodećih srpskih i hrvatskih građanskih partija.

Polazeći od kritike građanskih stranaka, Jaša Prodanović je smatrao da se njihova vođstva učestvovanjem u političkom životu od nastanka jugoslovenske države 1918. nisu držala svojih programa zaključno sa 1939. Stranke su se bez ikakvih načelnih razloga razdvajale u frakcije i spajale u koalicije. Svađale se i mirile, menjale šefove, imena i programe. „Jedan prevrtljivi političar koji je izjavljivao da bi bio republikanac i kad bismo imali englesku monarhiju učestvovao je u vladi koja je ukinula Vidovdanski ustav", napisao je. Razmišljajući o sve otvorenijem isticanju demokratskih načela u javnosti od strane mnogobrojnih vodećih partija, i gaženju istih u političkoj praksi, setno je i pomalo cinično zaključivao kako se sve u Jugoslaviji „podemokratisalo”: „Sirota demokratija. Koliko je rečima obla i gojazna: sva mast i salo, toliko je u delima suha i mršava: sama kost i koža". ${ }^{10}$ Nedemokratičnost političkih partija pre šestojanuarske diktature sagledavao je, između ostalog, u činjenici da su glasale za protivustavno uništenje Komunističke partije Jugoslavije, podržale „po zlu čuvenu Obznanu” (ovde je prvenstveno „prozivao” Demokratsku i Radikalnu stranku), donele antidemokratski čl. 4. Zakona o činovnicima, razrešavale na izborima voljom građana izabrane opštinske uprave, vršile, kad su bile u vlasti, velike pritiske pri izborima. U takvim okolnostima demokratija nije ni živela, ni životarila nego izdisala. ${ }^{11}$ Posle 6. januara 1929. i ukidanja višestranačkog života, u politici je nastalo „zlatno doba korupcije i srećno vreme za partijske otpadnike, nevernike, prebeglice i izdajnike. Na površinu je isplivao politički talog. Mnogima (...) bio je crn obraz ali puna torba” dok je "narod padao u tešku bedu i nevolju”. ${ }^{12}$

$\mathrm{Na}$ više puta postavljana pitanja od strane pojedinih političkih prvaka drugih stranaka zbog čega republikanci, kad se već ne mire sa „žalosnim” stanjem u državi, nisu ušli u opozicioni blok Udružene opozicije i radili sa njima protiv režima, Jaša Prodanović je odgovarao: „Nisu nas zvali”, iz straha da ih ne kompromituju. Šefovi Udružene opozicije „držali su u rukama dva gvožđa u vatri: tražili su poverenje odozdo, ali su želeli i podršku odozgo". ${ }^{13}$ Sve i da su ih zvali, republikanci bi odbili, jer bi sudelovanje u političkom režimu bez prethodnih javnih ograda i osuda njegovih nosilaca (što Udružena opozicija, prema mišljenju

Branko PETRANOVIĆ, „Političke snage Srbije 1941. i njihove podele”, Istorijski glasnik, sv. 1-2/1990.-1992., 73.82.

O sporazumu Cvetković-Maček videti: Ljubo BOBAN, Sporazum Cvetković-Maček, Beograd 1965.

J. M. PRODANOVIĆ, Lažna i prava demokratija, 1. (Arhiv SANU, Zaostavština Jaše M. Prodanovića, 14706/5)

Analizom teksta utvrdili smo da je pisan 1939. Stranice je brojevima obeležio Jaša Prodanović.

10 J. M. PRODANOVIĆ, Lažna i prava demokratija, 2.

11 Isto, 3.

12 Jaša M. PRODANOVIĆ, Dragi prijatelju, potrebno je da te obavestimo, Beograd 1939., 1.-2.

13 Isto, 2. 
Jaše Prodanovića, nije učinila) značilo priznanje svega što je od strane vlasti urađeno posle 6. januara. Udružena opozicija je bila organizovana bez ikakvog programa, opravdane parole, obeležene svrhe. Republikanci su „osetili” da nije reč o pravoj parlamentarnoj borbi, nego da je Vlatko Maček „želeo da prebroji svoje privrženike”. ${ }^{14}$ Razmatrajući apstinenciju Udružene opozicije u Skupštini, Prodanović je tvrdio da su političari bili birani za skupštinski rad „a ne za pričanje po zborovima”. Kao što su poslanici HRSS-a u Radićevo vreme grešili što se nisu borili u Skupštini, tako su i Mačekovi haesesovci ponavljali istu grešku. Političke nastupe Udružene opozicije „o združenosti opozicije” i „borbi za narod” nazvao je „starom, bajatom i izanđalom političkom robom”. koju će prva politička nepogoda „zbrisati” ostavljajući „samo zastareli i neupotrebljiv materijal”. ${ }^{15}$ Unutarpolitički život Kraljevine Jugoslavije propratio je stihovima srpskog pesnika Petra Petrovića Njegoša:

\section{Čudne bruke, grdne mješavine... \\ združio se Turčin s Crnogorcem... \\ ujedno su ovce i kurjaci. ${ }^{16}$}

U takvim okolnostima bolje je bilo uzdržati se od javnog rada nego rđavo raditi, ne trošiti snagu u „besmislenim podvizima”, već je čuvati za „pogodnija vremena” i „odlučniju borbu". ${ }^{17}$

Analiza unutarpolitičkog stanja obuhvatila je i hrvatsko pitanje. ${ }^{18}$ Pre sporazuma Cvetković-Maček avgusta 1939, ni Jaši Prodanoviću, kao nekada njegovom prijatelju i političkom saradniku Ljubomiru Stojanoviću, nije bilo jasno šta su Hrvati tačno tražili. ${ }^{19}$ Govorilo se o sporazumu, iako se ni u najkrupnijim potezima nisu znala njegova načela, šta žele Vladko Maček i Hrvatska seljačka stranka, a šta druge stranke. Prema mišljenju Jaše Prodanovića, u stvari starom mišljenju Ljubomira Stojanovića, činjenica da se HSS prva bunila protiv postojećeg položaja hrvatskog naroda u jugoslovenskoj državi nalagala je da se prva i izjasni o svojim zahtevima. Ne bez nezadovoljstva i prekora Hrvatima, primetio je da su u prvo vreme borbe za svoja prava bili republikanci i federalisti, da bi posle postali monarhisti i centralisti. Istovremeno, pitao se gde su se između ta dva suprotna politička pravca nalazile njihove državne težnje i ideali: „Znamo da su monarhisti, a znamo i da nisu ostali pri centralizmu. Ali gde su i na čemu su; šta žele i čemu teže to je javnom mnjenju nepoznato". ${ }^{20}$

Sporazum Cvetković-Maček nije mnogo uklonio nejasnoće Jaše Prodanovića ili ih je, u stvari, uklonio u pogledu zahteva Hrvata i srpsko-hrvatskih odnosa u Kraljevini Jugoslaviji. Šef srpskih republikanaca upozoravao je februara 1940. na njegove nepreciznosti, opasne po državni život u vremenu kada je veći deo najrazvijenije Evrope buktao u ratnom plamenu. Sporazum je direktno kršio čl. 116. Oktroisanog Ustava koji je propisivao „da se preduzete mere”

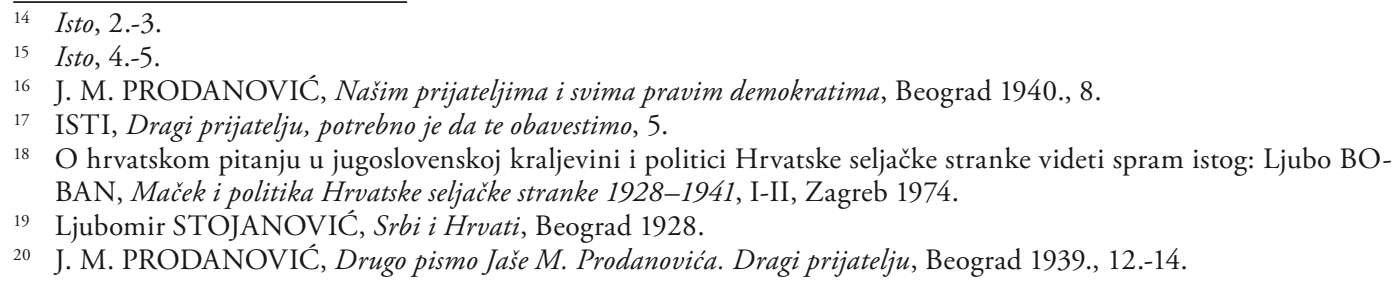

20 J. M. PRODANOVIĆ, Drugo pismo Jaše M. Prodanovića. Dragi prijatelju, Beograd 1939., 12.-14. 
u većem preuređenju državnog ustrojstva moraju naknadno podneti Narodnoj skupštini na odobrenje, i tek nakon ratifikacije u njoj stupaju na snagu. Međutim, sporazum je sklopljen bez upita Skupštine, koju je knez-namesnik Pavle Karađorđević odmah potom raspustio na neodređeno vreme i nastavio da ga provodi u život. Nedemokratski, protivparlamentaran i protivustavan postupak mogao se izbeći donošenjem novih zakona, kojima bi se nadogradio ustav, ili vraćanjem Vidovdanskog ustava što bi označilo vraćanje ustavnosti. U oba slučaja moglo se doći do Ustavotvorne skupštine koja je mogla doneti novi sporazumni Ustav, gde bi na demokratski način bilo rešeno i hrvatsko pitanje, ali je „,vođstvu HSS bilo lakše i ugodnije pristati na gaženje Ustava nego ući u 'srbijansku skupštinu'”. ${ }^{21}$ Narodnu slobodu postignutu sporazumom Jaša Prodanović protumačio je stihovima srpskog pesnika Jovana Jovanovića Zmaja:

Kad ti kažu da je ima, osetiš je u prsima,

kad osetiš kud te sprema, osetiš je da je nema. ${ }^{22}$

Ipak, priznavao je da je Sporazum imao i neke pozitivne odredbe, od kojih je kao najpozitivniju označio onu koja je izdvajanjem Banovine Hrvatske, sa prerogativima koji su je pratili, uvodila u stvari neku vrstu federativnog uređenja u Jugoslaviji. Nije želeo da presuđuje koliko je Sporazum bio iskren i trajan, ali je sa zebnjom primećivao da stvari nisu „išle glatko”, da su se u Hrvatskoj javljale pojave koje su zabrinjavale i Srbe i sve „iskrene privrženike jugoslovenstva”. Pojavljivale su se veće ili manje zloupotrebe dugo očekivane i teško zadobivene hrvatske autonomije - upotreba grube sile, prekoračivanje prava, što je bilo logičan rezultat dvadesetogodišnje borbe raznih režima protiv Hrvata. Neizbežne učinke dugog trpljenja namerno su podsticali „klerikalni i frankovački uticaji”. ${ }^{23}$ Verovao je da će sve navedene „nemile pojave iščeznuti” ukoliko i kod srpske i kod hrvatske strane bude „rodoljublja, trpeljivosti i takta”, ako u celoj zemlji bude zavladala socijalna i politička demokratija, sprovedeno federativno uređenje, poštovani ustav i zakoni „slobodno izabrane Narodne skupštine”. ${ }^{24}$

Kako se sve izglednije ratna opasnost primicala jugoslovenskoj državi, a rešenje hrvatskog pitanja još više opteretilo hrvatsko-srpske odnose, u prvom redu u Banovini Hrvatskoj, Jaša Prodanović je pozivao iskrene borce za demokratiju na dugu i upornu borbu, bez izgleda na brzu pobedu, bez klonuća pred prvim neuspesima. Ostajući veran svom načinu borbe sa nedaćama, hrabrio ih je citirajući Njegoševe stihove, po ko zna koji put u svom dugom političkom životu:

\section{Neka bude borba neprestana, \\ Neka bude što biti ne može, \\ Nek ad proždre, pokosi satana. \\ Na groblju će ponicí cvijeće, \\ $Z$ a daleko neko pokolenje. 25}

\footnotetext{
J. M. PRODANOVIĆ, Sporazum s Hrvatima, Beograd 1940., 5.

Isto, 9.

Isto, 14.

Isto.

J. M. PRODANOVIĆ, Lažna i prava demokratija, 6.
} 
Nezadovoljni pristupanjem Kraljevine Jugoslavije silama Osovine 25. III 1941. u Beču, generali Dušan Simović i Borivoje Mirković organizovali su vojni puč u zoru 27. III 1941. kojim su ukinuli namesništvo kneza Pavla Karađorđevića, oborili vladu Cvetković-Maček i proglasili sedamnaestogodišnjeg prestolonaslednika Petra II Karađorđevića punoletnim. Istog dana, rano ujutro srpski narod je spontano, nezadovoljan namesničkom „real-politikom" približavanja Nemačkoj i Italiji, na velikim demonstracijama u Beogradu i drugim jugoslovenskim gradovima izrazio svoje protivljenje članstvu Jugoslavije u Trojnom paktu, tražeći povratak politici savezništva sa Velikom Britanijom i približavanje Savezu sovjetskih socijalističkih republika. $S$ druge strane, svesna političke i vojne nespremnosti države za rat, nova jugoslovenska vlada Dušana Simovića uveravala je vođstvo nacističke Nemačke da ne gaji neprijateljske osećaje prema nemačkoj državi, ali sa druge strane nije dobila nikakvog odgovora. Ljut zbog dešavanja u Jugoslaviji, nemački vođa Adolf Hitler istog je dana označio srpski narod kao glavnog protivnika Nemačkog rajha i uzročnika nereda, naredivši napad na jugoslovensku državu u najkraćem vremenskom periodu. ${ }^{26}$ Nemačka vojna sila, potpomognuta saveznicima, Italijom, Mađarskom i Bugarskom, porazila je u roku od dve nedelje slabo naoružanu i neorganizovanu jugoslovensku kraljevsku armiju, izloženu izdaji u sopstvenim redovima. ${ }^{27}$ Adolf Hitler je podelio jugoslovenske zemlje svojim saveznicima i Jugoslaviju uklonio sa političke karte svog svetskog poretka. Srbija je svedena u „pretkumanovske granice” iz 1912. pod direktnom nemačkom okupacionom upravom, a srpski narod obespravljen i izložen masovnim ubistvima i progonima širom bivše jugoslovenske države.

Posle Aprilskog rata vođa jugoslovenskih komunista Josip Broz Tito je hteo da „razgovara sa vodećim političkim ličnostima bivših građanskih stranaka i obavijesti ih o novoj situaciji, nastaloj zbog okupacije, o hitnim zadacima” koje je preduzimala „na sebe Komunistička partija i Narodni front". ${ }^{28} \mathrm{U}$ želji da proširi političku osnovu budućeg neminovnog narodnog ustanka protiv zavojevača nekompromitovanim političarima J. B. Tito se „mnogo interesirao za pojedine političke ličnosti iz redova Jugoslovenske republikanske stranke i intelektualce raznih političkih struja izvan postojećih političkih građanskih organizacija". ${ }^{29}$ Zbog toga je predložio Ivanu Ribaru, jednom od vođa levog krila Demokratske stranke, da se sa takvim ljudima, dok je bio u Beogradu „poveže” i uspostavi bližu saradnju. Ivan Ribar je, između ostalih, uspostavio vezu sa Vojislavom Vujancem, članom Glavnog odbora JRS i bliskim saradnikom Jaše Prodanovića. Od njega je saznao da se jedan deo republikanaca opredelio za komuniste, dok se drugi, izgleda veći, okrenuo saradnji sa ravnogorskim pokretom pukovnika Dragoljuba Mihailovića. Posle Drugog svetskog rata Dragoljub Jovanović je tvrdio da su

\footnotetext{
26 Branko PETRANOVIĆ, Srbija u Drugom svetskom ratu, Beograd 1989., 25.-40.

27 Više o Aprilskom ratu: Velimir TERZIĆ, Slom Kraljevine Jugoslavije: uzroci i posledice poraza, I-II, Beograd 1982., 1984.; Mile BJELAJAC, Jugoslovensko iskustvo sa multietničkom armijom 1918-1988, Beograd 1999.

28 Ivan RIBAR, Uspomene iz narodnooslobodilačke borbe, Beograd 1961., 21.-22.

${ }_{29}$ Isto, 24. Komunistička partija Jugoslavije se na prvi pogled povinovala direktivama Kominterne (KI) o nenapadanju na nemačke okupatore da ih Nemci ne bi iskoristili kao jedan od povoda za napad na Sovjetski Savez. Međutim, svesno neminovnog skorog sukoba dvaju suprotstavljenih ideologija, nacionalsocijalističke nemačke i komunističke sovjetske, kao i sve okrutnije okupacione politike Nemaca i kvislinških režima prema srpskom narodu u Jugoslaviji, koja je izazivala prirodan otpor egzistencijalno ugroženih Srba, rukovodstvo KPJ se na terenu, bez znanja KI, spremalo za podizanje opšteg ustanka protiv zavojevača, čime se objašnjava i ova aktivnost Josipa Broza Tita. (B. PETRANOVIĆ, Srbija u Drugom svetskom ratu, 50.; ISTI, Strategija Draže Mihailovića, Beograd 2000., 32.)
} 
Vojislav Vujanc i (...) ugledni član (...) Jugoslovenske republikanske stranke, advokatski ortak Vasićev, ${ }^{30}$ Mladen Žujović i skoro svi republikanci u unutrašnjosti, pa i najleviji, kao Anta Todorović i Gliša Vukčević, bili povezani sa Dražom Mihailovićem, odlazili u njegov štab i sav Ravnogorski pokret smatrali svojom stvari. ${ }^{31}$

Navodno, „Jaša je sve to znao i odobravao”, jer je rekao Kirilu Saviću tokom 1944, kad ga je pozvao da pomogne nekim komunistima, „da je (...) sa svojim ljudima angažovan na drugoj strani". 32

U novonastalim okolnostima, u prvim godinama okupacije Jaša Prodanović se, prema rečima Vojislava Vujanca Ivanu Ribaru, posvetio naučnom radu. Šef republikanaca je svakog dana odlazio u Univerzitetsku biblioteku i pisao. Još se nije opredeljivao, nije želeo da „nagli”, ali je bilo sigurno da „neće izostati u odsudnom momentu, kada će morati svaki rodoljub da se odluči za borbu okupatora". ${ }^{33}$ Njegov sin, Borislav Prodanović, pridružio se posle kapitulacije jugoslovenske vojske partizanima, a otac ni posle godinu dana, jula 1942, kada su ga posetili braća Milan i Mladen Žujović, nije imao nikakve vesti o sinovljevoj sudbini. Zbog sina je bio pod nadzorom policije, koja mu je procenila pokućstvo i biblioteku i zapisala članove porodice. Iako oslabio, mnogo je radio i junački podnosio „lične muke, oskudicu, okupaciju”. ${ }^{34}$ Istog meseca policija je uhapsila Jašu Prodanovića zajedno sa snahom Milicom, ženom sina Borislava, i odvela najpre u Upravu grada, a potom u banjički logor. Mladen Žujović je zabeležio u dnevnik:

Gospođa Prodanović, kojoj sa svoje strane odmah telefonirah, kaže mi da je policija upala u njihov stan oko ponoći i da je odmah lišila slobode starca i njegovu snaju. Sav intelektualni Beograd je zgađen na ovu meru. Mi smo u kući utučeni. Jaši je 73 godine, ima ozbiljnu šećernu bolest i uremiju; on ovo ne može izdržati. (...) Sutra će Milan moliti Momčila Jankovića, koji je dobro sa Aćimovićem (Milanom - prim. A. L.), da njega zamoli da pusti g. Jašu. ${ }^{35}$

Mladen Žujović obavestio se i doznao da je hapšenje bilo „Aćimovićevo delo” ${ }^{36} \mathrm{Ne}$ postoji zapisnik sa isleđenja Jaše Prodanovića u logoru na Banjici, već samo registracioni list o privođenju, verovatno otud što je već sutradan pušten iz pritvora. Njegova snaha Milica ostala je nešto duže zatvorena, sve do meseca avgusta 1942.37

Među hartijama istaknutog republikanca u Arhivu SANU nalazi se dokument sa njegovim i imenima još nekoliko članova JRS koji su obeleženi kao delegati stranke za prvo zasedanje Antifašističkog veća naroda Jugoslavije u Bihaću decembra $1942 .{ }^{38} \mathrm{U}$ odsustvu ga je na zasedanju zamenio republikanac Vladimir Simić.

30 Dragiša Vasić, takođe republikanac, kasnije jedan od ideologa Ravnogorskog pokreta.

31 Dragoljub JOVANOVIĆ, Medaljoni III, Beograd 2008., 225.-226. Međutim, posle povratka u Beograd 1944. Ivan Ribar je doznao da je Vojislav Vujanac „mučen i prebijen umro u logoru na Banjici. On [V. Vujanac] je odbio svaku saradnju sa Acom Pavlovićem i Živkom Topalovićem i nije se pridružio njihovoj akciji na takozvanom 'Svetosavskom kogresu' održanom 1944. godine u selu Ba, uz sudjelovanje Draže Mihailovića, već ja zahtijevao od njih da se otpočne odmah sa oružanom akcijom protiv okupatora". (I. RIBAR, Uspomene iz narodnooslobodilačke borbe, 27.)

32 D. JOVANOVIĆ, Medaljoni III, 226.

33 Isto, 26., 32.

34 Mladen J. ŽUJOVIĆ, Ratni dnevnik II. Jugoslavija u Drugom svetskom ratu 1942-1944, Vrnjačka Banja 2004., 18.

Isti, 19

36 Isti.

37 Arhiv grada Beograda, 4190/MG-557.

38 Arhiv SANU, Zaostavština Jaše Prodanovića, 14706/24. 
Partizanske jedinice, dobro organizovane i opremljene vojnim materijalom zaplenjenim nakon kapitulacije Italije, držale su u proleće 1944. veliku slobodnu teritoriju u centralnim delovima Jugoslavije. Vojnu opremu u sve većim količinama je slala i Velika Britanija od jeseni 1943, primenjujući politiku podržavanja jugoslovenskih partizana u njihovom aktivnom otporu protiv Nemaca. Posle teških bojeva na Sutjesci i reorganizovanja narodnooslobodilačke vojske predstojale su borbe za oslobođenje cele Jugoslavije od nemačkog okupatora i njegovih saradnika, zbog čega je bilo nužno političko jedinstvo naroda Jugoslavije i mobilisanje svih raspoloživih snaga za izvojevanje konačne pobede. U želji da postigne političko jedinstvo u Jugoslaviji i ujedno izdvoji političke funkcije iz AVNOJ-a (sve više predstavnika državnih funkcija), KPJ je već početkom 1944, znatno pre oslobođenja Srbije, preduzela niz mera za organizovanje široke političke organizacije nazvane Jedinstveni narodnooslobodilački front - JNOF. JNOF-u su mogle pristupiti grupe građanskih političara i stranke izolovane od uticaja i kontrole stranih rukovodećih centara, nekompromitovane saradnjom sa okupatorom i njegovim saradnicima tokom Drugog svetskog rata. Prema istraživanjima Branka Petranovića, „JNOF je pružao mogućnost da se one stare građanske snage koje nisu bile okaljane kolaboracijom u sastavu JNOF usame i time spreči njihov politički rad van kontrole JNOF-a i apsorbuju građani patriotske vokacije... bio [je] pogodna forma organizacije za političko-moralni pritisak na snage koje su računale na deobu, uticaj ili na modifikaciju stvorenog stanja". ${ }^{39}$ Organizacija je naročito bila aktuelna u Hrvatskoj i Srbiji, jugoslovenskim zemljama u kojima su snage kontrarevolucije bile najjače i gde je tradicija stranačkog života bila prisutnija nego drugdje u Jugoslaviji. ${ }^{40}$

Srbija je bila među poslednjim ratnim pokrajinama koje su konstituisale front novembra 1944 (u Hrvatskoj se to zbilo maja iste godine). ${ }^{41}$ Kada je držan osnivački kongres JNOFa za Srbiju, nove revolucionarne vlasti su 11. ili 12. XI poslale automobil po Jašu Prodanovića, koji je, prema sećanju Dimitrija Đorđevića, „očekivao hapšenje kada su partizani ušli u Beograd” i „spremio ćebe i par čarapa za svaki slučaj”. ${ }^{42}$ Umesto hapšenja, posetioci Aleksandar Ranković i Edvard Kardelj su mu predložili, pošto su mu rekli da je njegov sin Borislav umro a unuk Jaša poginuo, da uđe u Front, jer ga „narod traži”. ${ }^{3}$ Odveli su ga u zgradu Kolarčevog univerziteta „izbacili na govornicu uz frenetičan pljesak delegata i publike na nogama”. Po sećanju Dragoljuba Jovanovića „Jaša nije bio navikao na tako bučne scene, zbunio se i verovatno oduševio. (...) Govorio je malo (...) najviše protiv monarhije i za republiku”. ${ }^{44}$ Potom je izabran u izvršni odbor JNOF-a. Na osnivačkoj skupštini KPJ je insistirala da je Narodni front jedinstvena, a ne koaliciona organizacija.

Krajem rata, u novim političkim okolnostima Jaša Prodanović je uzeo živo učešće. Osim što je ušao u Narodni front, od maja 1945. postao je i ministar za Srbiju u Privremenoj vladi Demokratske Federativne Jugoslavije. Najpreče mu je bilo da se u Jugoslaviji osigura uspostavljanje republikanskog oblika vladavine na „pravilnoj” demokratskoj osnovi. Na sednicama JNOF-a tokom 1945. insistirao je da se zauzme stav o pitanju opredeljivanja za monarhiju ili republiku, govorio je da su jedna i druga „kao dan i noć”. Iako je tvrdio je da

\footnotetext{
39 Branko PETRANOVIĆ, „Jedinstven narodnooslobodilački front - poreklo i karakter”, Istorijski glasnik, sv. 1-2/1975., 75.-78.

40 Isto, 79.

41 Dragoljub S. PETROVIĆ, Narodni front u Srbiji i put u jednopartijski život: 1941-1945, Beograd 1997., 150.

42 Dimitrije ĐORĐEVIĆ, Ožiljci i opomene II, Beograd 1995., 50.-51.

43 D. JOVANOVIĆ, Medaljoni III, 226.

44 Isto.
} 
je bolji „i apsolutizam nego demokratija u monarhiji”, na svakoj sednici fronta Srbije je ozbiljno i osnovano kritikovao predloge i odluke koje nisu poštovale ili su narušavale osnovne demokratske principe. ${ }^{45} \mathrm{Kad}$ je krajem 1944. izrađivana Deklaracija o političkoj osnovi JNOF-a Srbije, zahtevao je da se više istaknu elementi demokratije, koju je sagledavao kao političku i socijalnu. Prema njegovom od ranije isticanom shvatanju, postojanje krune kao političkog faktora onemogućavalo je u potpunosti ili delimično, zavisno od snage ličnosti kralja, punu slobodu političkog organizovanja naroda. Zbog toga je novoosnivana jugoslovenska republika trebala da podrazumeva punu slobodu političkog organizovanja, štampe, zbora i dogovora, sve one elemente bez kojih demokratska država nije mogla da postoji. ${ }^{46}$ Naročito je kritikovao stav Deklaracije o pravu naroda na samoopredeljenje sa mogućnošću otcepljenja, koji nisu imale ni velike federativne država poput Brazila, Sjedinjenih američkih država, Nemačke, Švajcarske. Strahovao je da se pozivanjem na ovaj stav i Makedonija mogla otcepiti od Jugoslavije i prisajediniti Bugarskoj, zbog čega je, između ostalog, smatrao da Skoplje i Kumanovo treba da budu deo federalne jedinice Srbije. Nije priznavao da su Makedonci poseban narod i da postoji makedonski književni jezik. ${ }^{47}$

Kao što nije priznavao nacionalnu posebnost Makedonaca, još više je od sebe odbijao bilo kakvu pomisao o crnogorskoj naciji, zbog čega se „naročito zamerio Đilasu”. ${ }^{48}$ Milovan Đilas je pisao da je crnogorski narod u ratu „pošao svojim putem, tj. putem borbe protiv okupatora, u zajednici sa Srbima, sa svim narodima Jugoslavije, putem borbe za istinsko nacionalno oslobođenje - za ravnopravnost u novoj državi koja treba da se rodi iz narodnog ustanka protiv zavojevača”. ${ }^{49} \mathrm{Na}$ tvrdnje srpskih građanskih političara da su Crnogorci zapravo Srbi i da ne treba dozvoliti cepanje srpstva odgovarao je kako "Crnogorci, nesumnjivo, pripadaju srpskoj grani južnoslovenskih plemena”, ali su im „putevi razvitka ka naciji bili kod jedne (u Srbiji) i kod druge (u Crnoj Gori) različiti. (...) Stvaranje nacije u Crnoj Gori počelo je čitavo stoljeće kasnije nego u Srbiji. (...) Proces formiranja crnogorske nacije" je trajao i 1945, a u Drugom svetskom ratu ,posebna crnogorska individualnost, ispoljavanje nacionalne svijesti i nacionalne osobitosti, najoštrije su došli do izražaja”. Rat je u izvesnom smislu označavo „kulminacionu tačku procesa formiranja Crnogoraca u posebnu naciju, posebnu nacionalnu individualnost". ${ }^{50}$ Najposle, M. Đilas je zaključio da komunisti nisu bili za federalnu Crnu Goru ni iz kakvih političkih razloga, niti su želeli da „cijepaju srpstvo. Mi (komunisti - prim. A. L.) smo za to jer smo uvjereni, jer znamo da to hoće crnogorski narod, a on to hoće jer se osjeća, jer jeste nešto posebno, posebni drukčiji 'Srbi' od svih Srba - Crnogorci”. 51

Jaša Prodanović nije imao ništa protiv da Crna Gora bude federalna jedinica, ali je uporno ukazivao na činjenicu da cela ,istorija, nauka i književnost ne pominju crnogorsku narodnost". ${ }^{52}$ Nezadovoljan i drugim političkim napisima i pogledima Milovana Đilasa, više puta mu je rekao: „Gospodine Đilas, vi ste darovit mlad čovek, ali se u politiku ne razumete". 53

\footnotetext{
D. S. PETROVIĆ, Narodni front u Srbiji i put u jednopartijski život, 160.

„Govor Jaše Prodanovića na velikom narodnom zboru 4 novembra o. g”, Republika (Beograd), 6. 11. $1945 ., 2$.

D. S. PETROVIĆ, Narodni front u Srbiji i put u jednopartijski život, 161.

D. JOVANOVIĆ, Medaljoni III, 226.

Dušan BOJKOVIĆ, „Milovan Đilas o nacionalnom i državnom pitanju Crne Gore”, Tokovi istorije, 20/2012., br. 1, 113.

Borba (Beograd), 1. 5. 1945., 3.

Isto.

D. S. PETROVIĆ, Narodni front u Srbiji i put u jednopartijski život, 161.

D. JOVANOVIĆ, Medaljoni III, 226.
} 


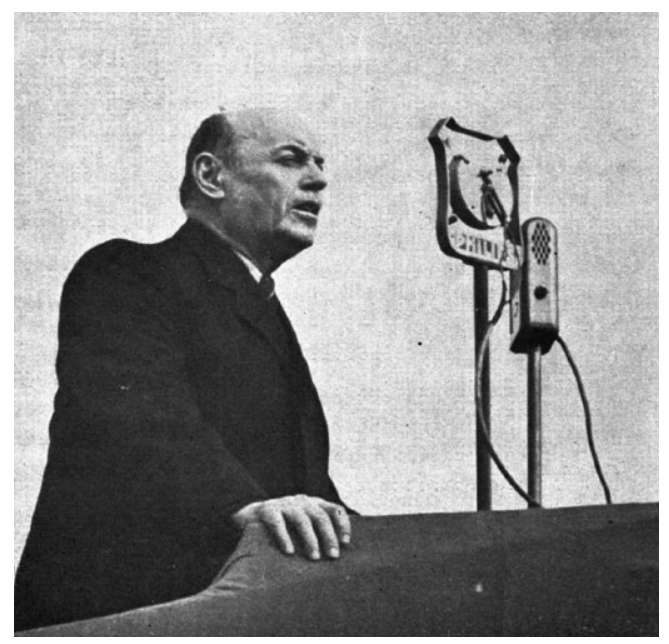

Slika 1. Jaša Prodanović na beogradskom Trgu Republike u predizbornoj kampanji 1945. godine
Prolaskom vremena, Jaša Prodanović je sve više ispoljavao različite poglede u odnosu na poglede KPJ na političku stvarnost nove Jugoslavije. Uoči izbora za Konstituantu, novembra 1945, republikanci su, pod utiskom sve većeg i očiglednijeg pritiska KPJ na političke stranke u frontu da slede političku liniju propisanu od komunista, pisali da Front

nije slučajna tvorevina, ni partijska ni vladavinska kombinacija jednog trenutka ili jednog istorijskog razdoblja (...) već istorijska nužnost, na koju je narod Jugoslavije upućivala reakcija mnogo pre neprijateljske najezde. (...) Zalaganje za održavanje narodnog fronta ne pomućuje (...) poglede i ne isključuje razumnu kritiku, koja se podiže i čuje sa mnogo strana, protiv pogrešaka neuputnog rada, čak i samovolje (...) izvesnih organa vlasti. ${ }^{54}$

Jaša Prodanović je bio svestan da u preobražaju zemlje nije išlo sve „glatko”, bez potresa, pogrešaka i zabluda, nedopuštenog pritiska „odozdo”, „štetnih zanosa i preterivanja”. „Zdrav razum” nije mogao uvek da brzo ublaži „raspaljene strasti”, zbog čega se još ponegde ispoljavala želja za osvetom, stradao „poneki pravednik a silio krivac”. Muke, patnje, stradanja i smrt najdražih po pravilu su izazivali „nadraženje nerava”, unosili „u srce gorčinu, porađa(li) mržnju i gnev, zasenjiva(li) politički vid, oslabljiva(li) moć trezvenog razmišljanja”, podsticali pobedioce za „neograničenim, beskompromisnim gospodarenjem”. 55 Međutim, „previranje” nije smelo da traje dugo. Bilo je potrebno, zarad opšteg dobra, da se blagovremeno stišaju „nabujale strasti, upitome naravi, ublaži razdraženost, (...) ne radi iz inata i sevapa, da se ne bude ni med ni jed”. Budući da je „rđava prošlost zatrovala dobru budućnost”, nova Jugoslavija trebalo je da svim „ispravnim građanima” obezbedi „spokojan život, prava na slobodu i imovinu neophodnu za življenje”. „Ne može biti“, pisao je Jaša Prodanović, „brzih i potpunih preokreta, ni naglih promena ljudske prirode. Nema čarobnih palica koje munjevitom brzinom preobraćaju pakao u raj" ${ }^{56}$ Tražio je da se stišaju sukobi unutar Fronta, ublaže partijski egoizam i politička isključivost.

Posle izbora za Konstituantu i negativnog iskustva republikanaca sa komunistima u predizbornoj kampanji, Jaša Prodanović je taktički izjavio stranim novinarima da $\mathrm{Na}$ rodni front nije bio „monolitna institucija, nego sporazum grupa i stranaka”. Odmah potom naglasio je da je bilo za „žaljenje što Republikanskoj stranci koja je Narodnom frontu pristupila iskreno i lojalno, nije pružena mogućnost da proširi bazu svoje akcije” budu-

Vojislav KOŠTUNICA - Kosta ČAVOŠKI, Stranački pluralizam ili monizam. Posleratna opozicija - obnova i zatiranje, Beograd 1990., 81.-82.

55 J. M. PRODANOVIĆ, „Na velikoj prekretnici”, Republika (Beograd), 6. 11. 1945., 1.

56 Isto. 
ći da nije bila „isključivo srbijanska ili srpska stranka". ${ }^{57}$ U stvari, ukazao je na činjenicu da Narodni front nije bio „koalicija ravnopravnih”, pošto je jedna stranka - KPJ - imala slobodu delovanja na teritoriji cele Jugoslavije, dok su sve ostale partije mogle da deluju samo u okviru pravila koja im je vodeća stranka odredila. ${ }^{58}$ Isticao je da je u okviru Narodnog fronta Republikanska stranka sarađivala „iskreno i čestito”, zbog čega nije bilo umesno kada su pojedini pripadnici Fronta (pre svega komunisti) govorili republikancima po selima i gradovima: „Vi vučete našu saku uz brdo. A kada je izvučete nećete dobiti ni kapi vode!". ${ }^{99}$ Još jednom je naglasio veli-

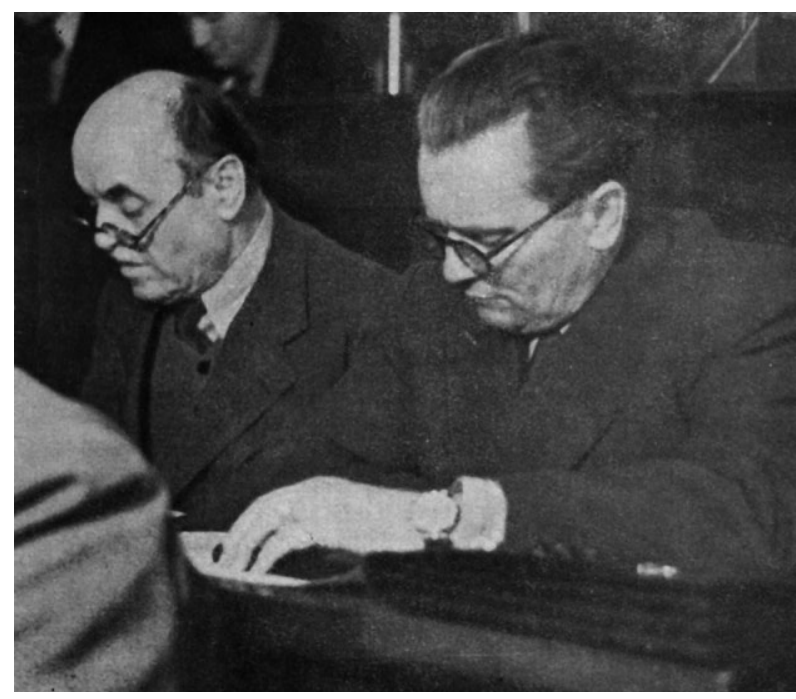

Slika 2. Jaša Prodanović s desne strane Josipa Broza Tita u Skupštini FNR Jugoslavije ku moralnu snagu JRS i istakao volju da sarađuje u Frontu „ako za tu saradnju budu obezbeđeni objektivni uslovi”. ${ }^{60}$

Komunisti se, međutim, u političkoj praksi nisu mnogo obazirali na opomene Jaše Prodanovića. Naprotiv, kako su vremenom zadobijali sve veću političku moć, postajali su bezobzirniji u odnosima sa drugim političkim strankama u okviru Fronta i van njega. Ponesen sve većim političkim učvršćivanjem KPJ, Radovan Zogović, jedan od njenih visokih funkcionera, samouvereno je tvrdio, u raspravi sa Jašom Prodanovićem oko pojedinih predloga zakona, januara 1946, da se „ova (komunistička - prim. A. L.) vlast nikada neće smijeniti”. Braneći osnovna načela demokratije o potrebi smene vlasti Jaša Prodanović je obrazlagao:

Ja stojim na principijelnom gledištu da jedan režim treba da ima takve principe da je njemu svejedno bio na vlasti ili van vlasti. (...) Može jedna stranka da počne sa idealizmom, ali da to izmeni kada ostane duže vremena na vlasti. (...) Ne može se garantovati ni za jednu generaciju da će ostati u duhu ideja sa kojima je počela a još manje za druge generacije. Teško je ostati na vlasti dosledan onome što se u opoziciji radilo. ${ }^{61}$

U veće neslaganje sa novim vlastima ponovo je došao jula 1946, kada je sa svojim republikancima u Narodnoj skupštini Srbije otvoreno ustao protiv oduzimanja mandata opozicionaru Dragoljubu Jovanoviću, vođi Narodne seljačke stranke. Kao kada se davne 1920. protivio nedemokratskom i neparlamentarnom izbacivanju komunističkih poslanika

\footnotetext{
K. ČAVOŠKI - V. KOŠTUNICA, Stranački pluralizam ili monizam, 82.

Isto.

59 „Izjava Jaše M. Prodanovića za inostranu štampu”, Republika (Beograd), 27. 11. 1945., 1.; K. ČAVOŠKI - V. KOŠTUNICA, Stranački pluralizam ili monizam, 82.

60 „Izjava Jaše M. Prodanovića za inostranu štampu”, 1.

${ }_{61}$ K. ČAVOŠKI - V. KOŠTUNICA, Stranački pluralizam ili monizam, 83.
} 
iz Narodne skupštine Kraljevine Jugoslavije, isto je činio i 26. VII 1946. braneći u novim okolnostima od nekadašnjih progonjenih nove prognanike. Prilikom odlučivanja o sudbini Dragoljuba Jovanovića „Divac i Veljko Kovačević su izašli iz dvorane da ne bi morali da glasaju, Sreten Vukosavljević je oborio glavu i nije digao ruku, dok je Jaša sa celom svojom grupom ustao na noge, glasao protiv isključenja i stenografima diktirao izjavu." ${ }^{62}$ Objašnjavajući svoj stav, Jaša Prodanović je pisao da za njega „ne postoje dve strane barikade: jedna... u opoziciji” i „druga” u vlasti:

Političke ideje nisu matematičke aksiome ili verske dogme - nepromenljive i neprikosnovene. Za razumnog i ozbiljnog političara glavno je da (...) [između ostalog] ni u kakvom slučaju ne odobrava da se radi protivno ustavu i zakonu. ${ }^{63}$

U ustavu nije bilo ni reči o tome kada, kako i zbog čega se poslaniku mogao oduzeti mandat, ali je bilo u članu 18. poslovnika Skupštine Srbije. Poslanik je gubio mandat u slučaju smrti, osude na nečasno delo, rušenja ugleda Skupštine neprikladnim ponašanjem, neopravdanog i stalnog odsustvovanja sa sednica. Za Jašu Prodanovića, slučaj Dragoljuba Jovanovića bio je „čisto načelno, a nikako lično pitanje”, zbog čega je bio uveren da vođa Seljačke stranke nije potpadao ni pod jednu od navedenih inkriminacija. Osim toga, bio je nepravilan i način na koji je predlog Mandatnog odbora iznesen pred Skupštinu, jer je bio velik broj poslanika neupućenih u samo pitanje, zbog čega nisu ni mogli diskutovati u parlamentarnoj debati, osnovnoj pretpostavci demokratske institucije. ${ }^{64}$ Ovo je, međutim, bilo i poslednje veće javno neslaganje sa politikom komunista.

Pored „nošenja” sa komunistima, Jaša Prodanović je morao da se bori i sa velikim delom srpskog građanstva, koje je u njegovim postupcima videlo izdaju srpskog naroda i vređanje „srpskih svetinja”. Bio je prozvan „od izvesnog dela čaršije” zbog članka „Vladaoci u našoj narodnoj poeziji”, objavljenog u književnom dodatku božićnog broja Politike 1944, gde je „ukratko i sažeto izneseno nepovoljno mišljenje (...) naroda o vladaocima”. ${ }^{65}$ Iako je istakao da nije sudio o vladaocima, „nego samo i jedino iznosio ono što su narodni pesnici o njima pevali, (...) jedna učiteljica u penziji bila je skandalizirana” njegovim člankom, zbog čega mu je uputila vrlo neprijatno pismo. Zamerajući mu nepoznavanje istorijskih činjenica, napisala je da „Turci nisu došli u Evropu za vreme sv. Save”. Jaša Prodanović je rekao da je znao činjenice, ali da je „narod tako pevao u svojim pesmama”, a on niti je „hteo, niti (...) smeo ispravljati hronološke pogreške" narodnih pesama pri njihovom navođenju. ${ }^{66} \mathrm{Na}$ zamerku „zbog čega je baš sad izneo nepovoljno mišljenje našeg naroda o svojim vladaocima" odgovarao je:

Pa kad ću ga, po Bogu, izneti ako neću sad (...) kad je rešavanje o republici na dnevnom redu? Moji prijatelji i ja pisali smo protiv monarhije i vladaoca četvrt veka. (...) Pa zar sad da prebrišem dvadeset i pet godina borbe i da štedim zle i opake vladaoce? I članak u Politici i ovaj sad u Republici imaju za svrhu da se pošteni ljudi (...) zadobiju za republiku. ${ }^{67}$

\footnotetext{
D. JOVANOVIĆ, Medaljoni III, 228.

„Jedno rešenje Narodne skupštine Srbije”, Republika (Beograd), 30. 7. 1946., 1. 
„Tako je bilo u Srbiji. Ali”, završavao je Jaša Prodanović svoj članak, „nisu bili bolji ni vladari u drugim jugoslovenskim zemljama". ${ }^{68}$

Nakon isključenja Dragoljuba Jovanovića iz Skupštine Jaša Prodanović se polako povlačio iz aktivne politike. Vremenom je u Republici sve više pisao o prošlom dobu, borbama za parlamentarizam i demokratiju u Kraljevini Srbiji, narodnim basnama, bajkama i poslovicama, pokušavajući da novim vlastima, čiji je i sam deo bio, ukaže na manje ili veće pogreške. I pored svih teškoća, uporno je čuvao individualnost Republikanske stranke. Dragoljub Jovanović sećao se da „su neki njegovi (Jašini - prim. A. L.) ljudi zahtevali da i on pređe u opoziciju”, ali je "Jaša rekao: Grol i Dragoljub mogu da budu opozicija, mi ne možemo, jer je u pitanju republika... svejedno kakva. U tome je bio dosledan. Istrajao je do smrti”. ${ }^{69}$

\section{$\cos$}

\section{Jaša Prodanović in World War II}

Jaša Prodanović (1867-1941), journalist, literary critic and politician, was one of the most vocal supporters of introducing a republican system in the Yugoslav state created in 1918. In the political life of the Kingdom of Yugoslavia, he was an advocate for the creation of a Federal Republic of Yugoslav people. Immediately before the breakout of World War II (1939-1940), as the head of the Yugoslav Republican Party, he addressed the public via several "political letters to friends". He remarked on the long lasting political crisis in the state that was caused by unyielding state centralism and national unitarism, the disregard for democratic principles by monarchist regimes and the undemocratic way in which the Cvetković-Maček agreement of August 1939 solved the Croatian national question. He also warned about the emergence of certain political forces in Croatia which went against the idea of a union of equal Yugoslav peoples. He saw the way out of the political crisis in a general election for a constituent assembly which would determine the polity of the Yugoslav state in a democratic manner and establish equality among the peoples within the Yugoslav state. When the war reached Yugoslavia in April 1941, and the country was occupied and dissolved by Axis powers and their allies, Jaša Prodanović mostly focused on scholarly work. Still, he maintained contacts with resistance movements, both with the pro-monarchy one led by Dragoljub Mihailović and the communist one led by Josip Broz Tito. Sources disagree on the level of his involvement with those movements. The victory of the partisans, with their determination to establish a republic in Yugoslavia, meant the realization of Jaša Prodanovićs lifelong political dream. Therefore, he did not hesitate to support them. His support, however, did not entail silence when it came to the new government's mistakes. Prodanović protested against the government's disregard of demo-

68 Isto.

69 D. JOVANOVIĆ, Medaljoni III, 228., „Na sednicama vlade (...) Jaša je uporno isticao veoma važno pitanje da ministri plaćaju svoje telefonske razgovore kao što je to bilo u Srbiji pre Prvog rata. Kada bi na sednicama kabineta stavljao zamerke na pojedine zakonske projekte, rekli bi mu: 'Čika-Jašo, mi smo u revoluciji!' Na to bi Jaša (...) odgovarao: 'A, tako. Revolucija. Molim lepo!'(...) ipak često [je] intervenisao u korist osuđenih pripadnika starog Beograda.” (D.

ĐORĐEVIĆ, Ožiljci i opomene II, 51.) 
cratic principles on more than one occasion (for instance, when Dragoljub Jovanović was evicted from the assembly). He managed to keep the Yugoslav Republican Party together until his death in 1948.

Keywords: Jaša Prodanović, Yugoslav Republican Party, World War II, People’s front, communists, republic

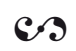

\section{Literatura}

Mile BJELAJAC, Jugoslovensko iskustvo sa multietničkom armijom 1918-1988, Beograd 1999.

Ljubo BOBAN, Maček i politika Hrvatske seljačke stranke 1928-1941, I-II, Zagreb 1974.

Ljubo BOBAN, Sporazum Cvetković-Maček, Beograd 1965.

Dušan BOJKOVIĆ, „Milovan Đilas o nacionalnom i državnom pitanju Crne Gore”, Tokovi istorije, 20/2012., br. 1, 106.-134.

Dimitrije ĐORĐEVIĆ, Ožiljci i opomene II, Beograd 1995.

Branislav GLIGORIJEVIĆ, Parlament i političke stranke u Jugoslaviji (1919-1929), Beograd 1979.

Branislav GLIGORIJEVIĆ, „Državno i društveno uređenje Jugoslavije u gledištima srpskih republikanaca (1919.-1925.)", Istorija XX veka, 3/1985., br. 2, 7.-33.

Dragoljub JOVANOVIĆ, Medaljoni III, Beograd 2008.

Slobodan JOVANOVIĆ, Vlada Aleksandra Obrenovića, II, Beograd 1990.

Vojislav KOŠTUNICA - Kosta ČAVOŠKI, Stranački pluralizam ili monizam. Posleratna opozicija - obnova i zatiranje, Beograd 1990.

Andrej MITROVIĆ, Vreme netrpeljivih. Politička istorija velikih država Evrope 1919-1939, Beograd 2012.

Branko PETRANOVIĆ, „Jedinstven narodnooslobodilački front - poreklo i karakter”, Istorijski glasnik, sv. 1-2, Beograd 1975., 75.-78.

Branko PETRANOVIĆ, Revolucija i kontrarevolucija u Jugoslaviji 1941-1945, I-II, Beograd 1983.

Branko PETRANOVIĆ, Istorija Jugoslavije, I-III, Beograd 1988.

Branko PETRANOVIĆ, Srbija u Drugom svetskom ratu, Beograd 1989.

Branko PETRANOVIĆ, „Političke snage Srbije 1941. i njihove podele”, Istorijski glasnik, sv. 1-2, Beograd 1990.-1992., 73.-82.

Branko PETRANOVIĆ, Strategija Draže Mihailovića, Beograd 2000.

Dragoljub S. PETROVIĆ, Narodni front u Srbiji i put u jednopartijski život (1941-1945), Beograd 1997.

Olga POPOVIĆ OBRADOVIĆ, Parlamentarizam u Srbiji od 1903. do 1914. godine, Beograd 1998.

Mira RADOJEVIĆ, Udružena opozicija 1935-1939, Beograd 1996.

Mira RADOJEVIĆ, Naučnik i politika. Politička biografija Božidara V. Markovića (1874-1946), Beograd 2007.

Jaša M. PRODANOVIĆ, Dragi prijatelju, potrebno je da te obavestimo, Beograd 1939.

J. M. PRODANOVIĆ, Drugo pismo Jaše M. Prodanovića. Dragi prijatelju, Beograd 1939. 
J. M. PRODANOVIĆ, Lažna i prava demokratija. (Arhiv SANU, Zaostavština Jaše M. Prodanovića, 14706/5)

J. M. PRODANOVIĆ, Našim prijateljima i svima pravim demokratima, Beograd 1940.

J. M. PRODANOVIĆ, Sporazum s Hrvatima, Beograd 1940.

Suzana RAJIĆ, Aleksandar Obrenović. Vladar na prelazu vekova - sukobljeni svetovi, Beograd 2011. Spomenica Jaše M. Prodanovića, Beograd 1958.

Ivan RIBAR, Uspomene iz narodnooslobodilačke borbe, Beograd 1961.

Ljubomir STOJANOVIĆ, Srbi i Hrvati, Beograd 1928.

Todor STOJKOV, Opozicija u vreme šestojanuarske diktature 1929-1935, Beograd 1969.

Velimir TERZIĆ, Slom Kraljevine Jugoslavije: uzroci i posledice poraza, I-II, Beograd 1982., 1984.

Ljubinka TRGOVČEVIĆ, Naučnici Srbije i stvaranje jugoslovenske države 1914-1920, Beograd 1986.

Dragiša VASIĆ, Devetsto treća (Majski prevrat), Beograd 1925.

Mladen J. ŽUJOVIĆ, Ratni dnevnik II. Jugoslavija u Drugom svetskom ratu 1942-1944, Vrnjačka Banja 2004.

\section{Arhivska grada}

Arhiv SANU, Zaostavština Jaše M. Prodanovića.

Arhiv grada Beograda, 4190/MG-57.

\section{Štampa}

Borba (Beograd), 1945.

Republika (Beograd), 1945.-1946. 